\title{
Blocking layers for nanocomposite photoanodes in dye sensitized solar cells: Comparison of atomic layer deposition and $\mathrm{TiCl}_{4}$ treatment
}

Venkata Manthina ${ }^{\mathrm{a}, \mathrm{b}}$, Alexander G. Agrios ${ }^{\mathrm{a}, \mathrm{b}}$

a, Department of Civil \& Environmental Engineering, University of Connecticut, 261 Glenbrook Rd Unit 2037, Storrs, CT 06269, USA

b, Center for Clean Energy Engineering, University of Connecticut, 44 Weaver Rd, Storrs, CT 062695233, USA

\begin{abstract}
Charge recombination at the electrode/electrolyte interface can be prevented by efficient blocking layers. Here, $\mathrm{TiO}_{2}$ blocking layers have been deposited using atomic layer deposition (ALD) and $\mathrm{TiCl}_{4}$ treatment. The number of $\mathrm{TiO}_{2} \mathrm{ALD}$ cycles was optimized for $\mathrm{I}^{-} / \mathrm{I}_{3}{ }^{-}$and $\mathrm{Fc} / \mathrm{Fc}^{+}$electrolytes. The optimized $\mathrm{TiO}_{2}$ ALD films' performance was compared with the $\mathrm{TiCl}_{4}$ treated films. $\mathrm{TiCl}_{4}$ treated films performed better than the ALD deposited films, attributed to reduction of the defects, which act as active sites of recombination.
\end{abstract}




\section{Introduction}

In the dye-sensitized solar cell (DSSC), charge recombination at the semiconductor/electrolyte interface is a major loss pathway, and particularly dominant at low light intensities[1]. The classic $\mathrm{I}^{-} / \mathrm{I}_{3}{ }^{-}$electrolyte has slow recombination kinetics, but alternatives have been sought due to its large overpotential loss, complex electrochemistry and corrosive nature. Other redox couples like $\mathrm{Fc} / \mathrm{Fc}^{+}$ [2], $\mathrm{Co}^{2+} / \mathrm{Co}^{3+}$ [3] and $\mathrm{Mn}^{3+} / \mathrm{Mn}^{4+}$ [4] have the benefits of simple single electron transfers and minimized overpotential loss, but have higher recombination rates. The DSSC record efficiency was achieved with a cobalt complex but required an especially thin semiconductor film to offset the relatively high recombination rate [5]. Blocking layers are widely used in DSSC to prevent recombination of the electron in the semiconductor or FTO with the electrolyte. Blocking layers are often thin insulating layers of $\mathrm{TiO}_{2}[6], \mathrm{ZnO}[7,8], \mathrm{ZrO}_{2}[9,10], \mathrm{SiO}_{2}[9], \mathrm{Al}_{2} \mathrm{O}_{3}[9,11]$, $\mathrm{MgO}[12,13], \mathrm{HfO}_{2}[14], \mathrm{CdO}[15]$, or polysiloxane[16] deposited on working electrode by various techniques like spray pyrolysis[17], sputtering[18], spin coating[19], dip coating[20], chemical vapor deposition[21], sol-gel deposition[9], $\mathrm{TiCl}_{4}$ treatment[6], chemical bath deposition[22] or atomic layer deposition[23]. 

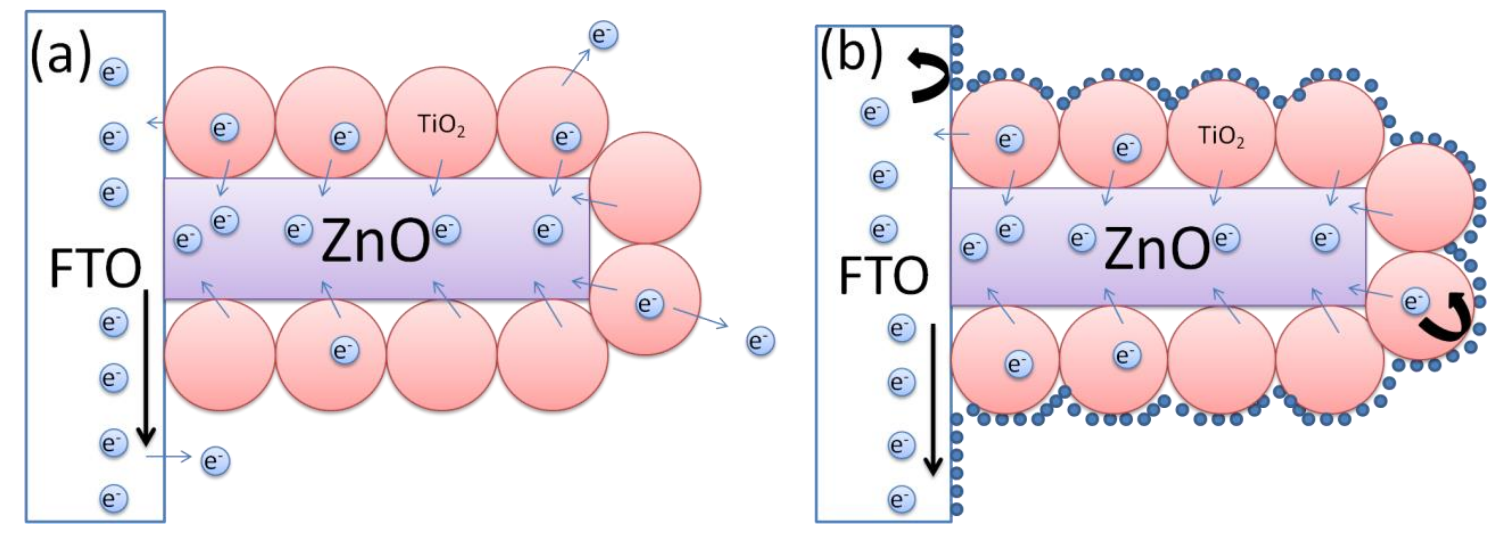

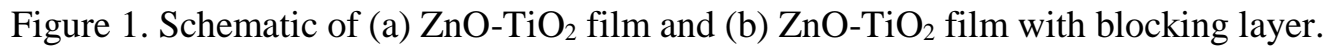

The ideal blocking layer should cover the entire surface of the FTO and $\mathrm{TiO}_{2}$ to prevent recombination and should not prevent electron injection. Chemical bath deposition barrier layers often increased the performance of the DSSC, but non uniform growth of barrier layers and lower precision of thickness control is observed. This led to growth of atomic layer deposition (ALD) as an alternative to chemical bath deposition. ALD offers precision thickness control in the ångström range and uniform coating. The thickness of the barrier layer is important as it can prevent electron injection, overshadowing the effect of reducing recombination or improving voltage of cell due to a conduction band rise [24]. In this report we used two simple techniques for the synthesis of the blocking layers on $\mathrm{ZnO}-\mathrm{TiO}_{2}$ films. Atomic layer deposition and $\mathrm{TiCl}_{4}$ treatment were used due to low temperature and large area synthesis. We analyzed the effect of the thickness of the blocking layers on DSSC performance in conventional $\mathrm{I}^{-} / \mathrm{I}_{3}^{-}$electrolyte and the fast recombining $\mathrm{Fc} / \mathrm{Fc}^{+}$ electrolyte. The results provide understanding of the role of blocking layer thickness and insight for optimizing DSSC and other electrochemical processes like water splitting. 


\section{Experimental}

Reagents and Materials. All chemicals were purchased from Sigma-Aldrich (USA) and were ACS grade. N719 was purchased from Dyesol (Australia). $\mathrm{SnO}_{2}: \mathrm{F}$ glass (FTO, transmission> $80 \%$ in the visible spectrum; sheet resistance $8 \Omega / \square$ ) was purchased from Hartford Tec Glass (USA).

Electrode Fabrication. $\mathrm{ZnO}-\mathrm{TiO}_{2}(\mathrm{ZT})$ films are synthesized as reported previously [25]. $\mathrm{TiCl}_{4}$ treatment was carried by immersing the ZT films in $40 \mathrm{mM} \mathrm{TiCl}_{4}$ solution[6] at $4^{\circ} \mathrm{C}$ for 30 minutes and rinsed in deionized water and ethanol[26]. ALD of $\mathrm{TiO}_{2}$ on the $\mathrm{ZnO}-\mathrm{TiO}_{2}$ films was carried out using a Cambridge Nanotech Savannah S100 using successive pulses of titanium ispopropoxide $\left(75^{\circ} \mathrm{C}\right)$ and deionized water $\left(25^{\circ} \mathrm{C}\right)$ and using nitrogen as the carrier gas inside the vaccum chamber with base pressure of 2 mtorr. The substrate was held at $200^{\circ} \mathrm{C}$ temperature inside the ALD reactor. After the pulse of titanium ispopropoxide $(14 \mathrm{~s})$ and water $(7 \mathrm{~s})$ the precursors were confined in the reactor for $30 \mathrm{~ms}$ to ensure complete coverage of the $\mathrm{TiO}_{2}$ inside the mesopores of the ZT films. The chamber was flushed with nitrogen for 30 seconds between cycles to remove any byproducts. The films were sintered on a titanium hot plate at $500^{\circ} \mathrm{C}$. This $\mathrm{ALD}$ process was previously measured to deposit $0.04 \mathrm{~nm}$ of $\mathrm{TiO}_{2}$ per ALD cycle [27].

\section{Dye Loading}

Sensitization. After sintering at $500^{\circ} \mathrm{C}$, films were allowed to cool to $100^{\circ} \mathrm{C}$ then immediately immersed in $0.3 \mathrm{mM} \mathrm{N719}$ in ethanol. After 12 hours they were removed and rinsed in acetonitrile and dried in air. The amount of N719 adsorbed by films was measured by immersion of a dyed film in aqueous $0.1 \mathrm{M} \mathrm{NaOH}$ to desorb the dye, followed by spectroscopic determination of the dye concentration, as we reported previously [25]. 
Solar Cell Assembly. Each sensitized electrode was sealed against a counter electrode on a hot plate at $120^{\circ} \mathrm{C}$ using a hot-melt plastic frame (Solaronix, Meltonix 1170, $25 \mu \mathrm{m}$ thick), applying light pressure with a glass rod. The assembled cell was filled with electrolyte through two holes in the counter electrode. The holes were then sealed using hot-melt plastic and a thin glass cover slide. The exposed conducting glass leads of each electrode were coated with copper tape (3M) for improved electrical conductivity.

Electrolyte Composition. Minimal electrolyte recipes were used to exclude complications due to interactions with the various additives that are commonly used. Iodide/triiodide $\left(\mathrm{I}^{-} / \mathrm{I}_{3}^{-}\right)$electrolyte was prepared with $0.5 \mathrm{M}$ tetrabutylammonium iodide and $0.05 \mathrm{M}$ iodine $\left(\mathrm{I}_{2}\right)$ in 3-

methoxypropionitrile. The ferrocene/ferrocenium $\left(\mathrm{Fc} / \mathrm{Fc}^{+}\right)$electrolyte contained $0.1 \mathrm{M}$ ferrocene and $0.05 \mathrm{M}$ ferrocenium hexafluorophosphate (Aldrich) in 3-methoxypropionitrile. The $\mathrm{Fc} / \mathrm{Fc}^{+}$ electrolyte was prepared fresh and deoxygenated by bubbling nitrogen 10 minutes prior to cell fabrication to minimize reaction of ferrocene with oxygen.

Solar Cell Characterization. Current-voltage $(J-V)$ measurements were made using Keithley 2400 source/meter controlled by a PC, while irradiating at $100 \mathrm{~mW} / \mathrm{cm} 2$ (1 sun) with AM $1.5 \mathrm{G}$ simulated sunlight produced by a solar simulator (Newport 91160), calibrated against a silicon reference cell with KG5 filter (PV Measurements, Inc., Boulder, CO). The DSSC active area was $1 \mathrm{~cm}^{2}$.

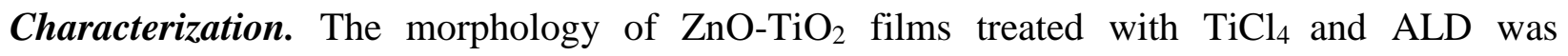
investigated by scanning electron microscopy (FEI Quanta FEG250 SEM in High vacuum mode) with attached EDX, and characterized by X-ray powder diffraction (XRD) using a Bruker D8 
Advance $\mathrm{X}$-ray diffractometer using $\mathrm{Cu} \mathrm{K} \alpha$ radiation $(\lambda=0.154178 \mathrm{~nm})$ at a scanning rate of $0.04^{\circ}$ $\mathrm{s}^{-1}$ in the $2 \theta$ range from $10^{\circ}$ to $90^{\circ}$.

\section{Results and Discussion}

\section{$\mathrm{ALD}^{\mathrm{TiO}}{ }_{2}$ bocking layers on $\mathrm{ZnO}-\mathrm{TiO}_{2}$ films}

Figure 2 shows $\mathrm{SEM}$ images of hybrid $\mathrm{ZnO}$ nanorod $-\mathrm{TiO}_{2}$ nanoparticle (ZT) films coated with $\mathrm{TiO}_{2}$ blocking layers of varying thickness by ALD. The increasing thickness of the blocking layer with increasing number of ALD cycles is apparent in the images. As the number of cycles goes into the hundreds it can be seen that the nanoparticles are encased in a thick $\mathrm{TiO}_{2}$ coating. This has the effect of closing the small pores between nanoparticles, which can be expected to reduce the total surface area.
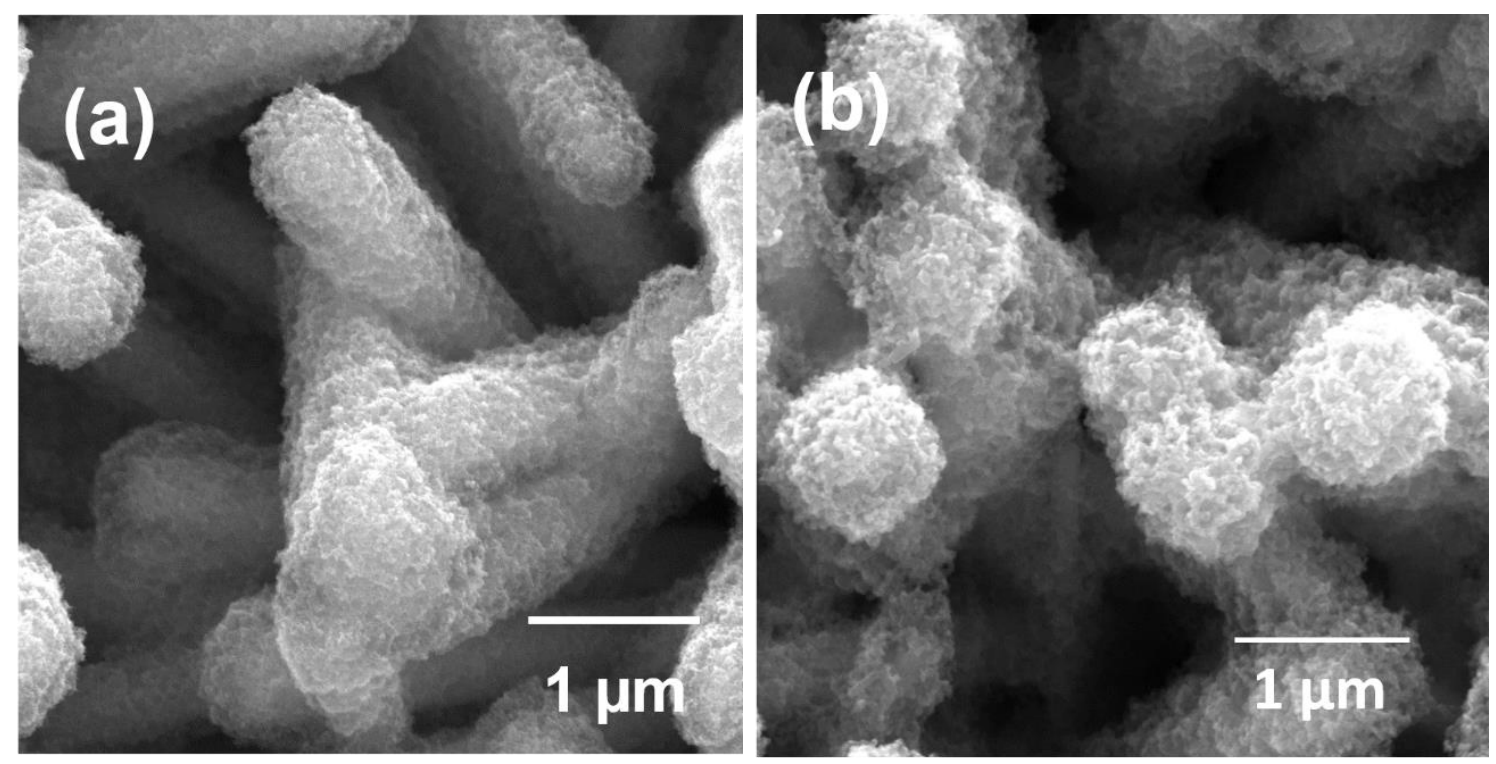

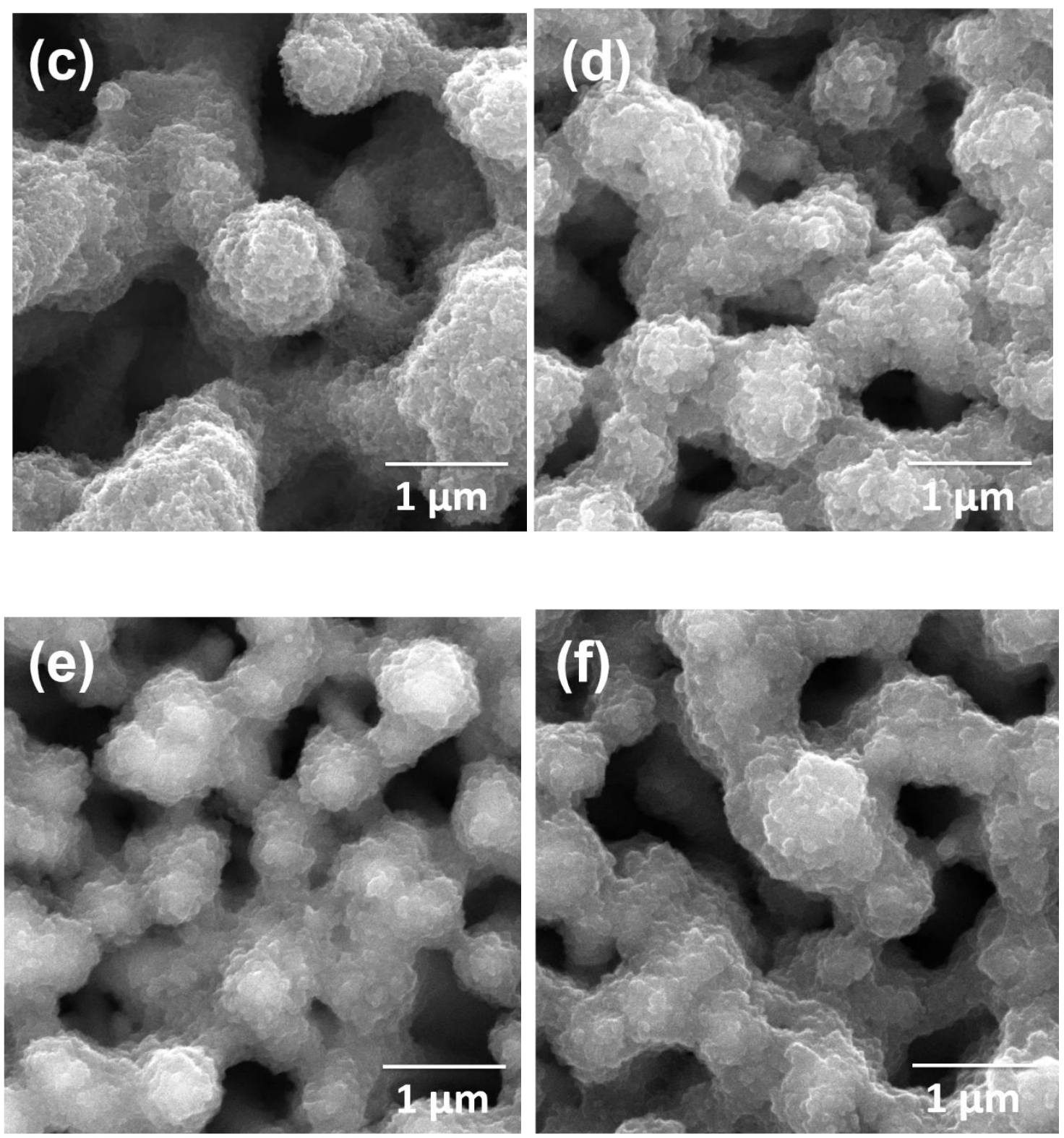


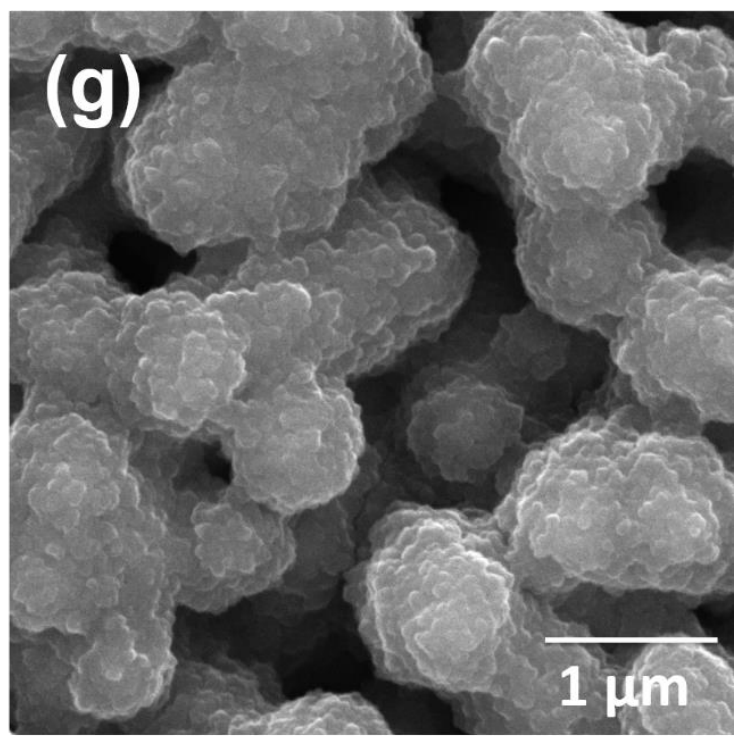

Figure 2. ALD of $\mathrm{TiO}_{2}$ on $\mathrm{ZnO}-\mathrm{TiO}_{2}$ (ZT) films (a) 0, (b) 40, (c) 100, (d) 200, (e) 300, (f) 400 and (g) 500 cycles.

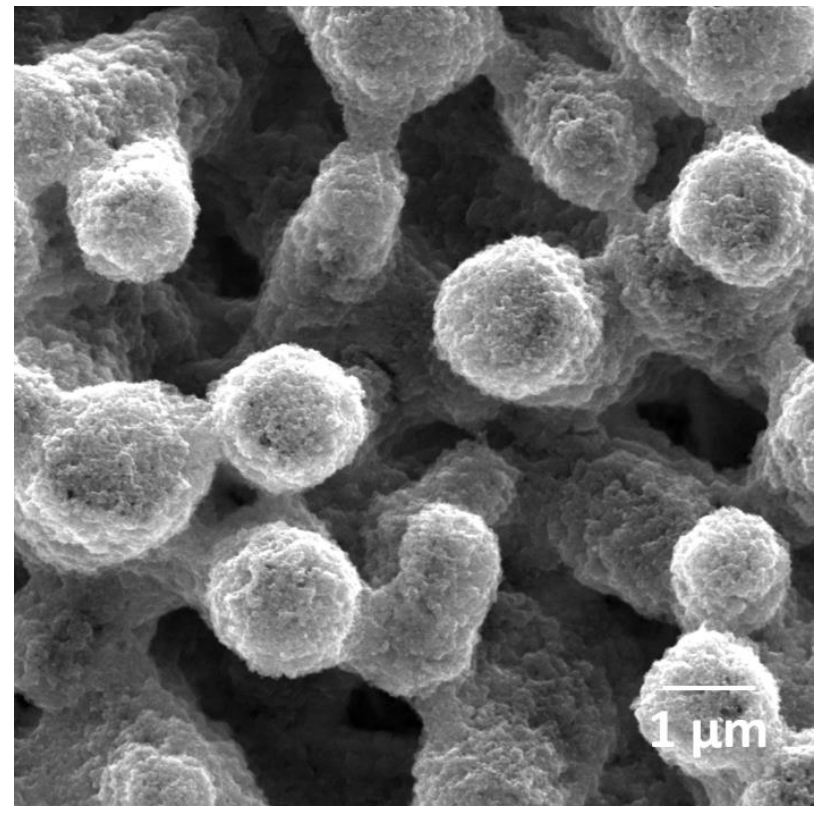

Figure 3. SEM image of $\mathrm{TiCl}_{4}$ treated ZT Film. 
Figure 3 shows an SEM image of a ZT film coated with a $\mathrm{TiO}_{2}$ blocking layer via $\mathrm{TiCl}_{4}$ treatment. This resembles the thinnest of the ALD blocking layers we produced. This is to be expected, as previous studies indicate $\mathrm{a} \mathrm{TiO}_{2}$ particle growth of about $1 \mathrm{~nm}$ after $\mathrm{TiCl}_{4}$ treatment [28].

From the EDX spectrum in Figure 4 we can compare the mass ratio of Ti to ( $\mathrm{Ti}+\mathrm{Zn}$ ) between the two coatings on ZT films, which is $2.63 \%$ Ti for a 100 -cycle ALD film and $3.22 \%$ Ti for a $\mathrm{TiCl}_{4}$ treated film.

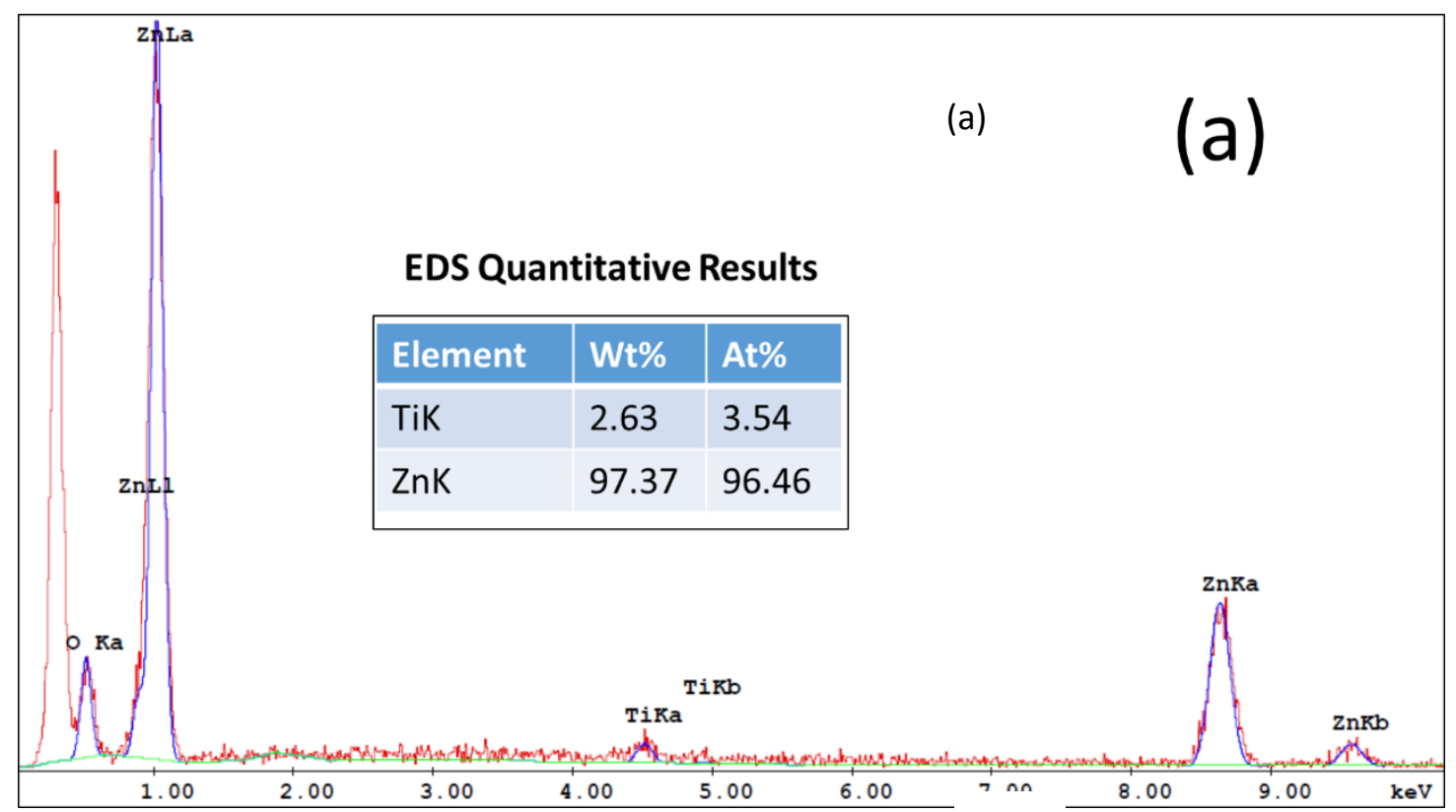

(b) 


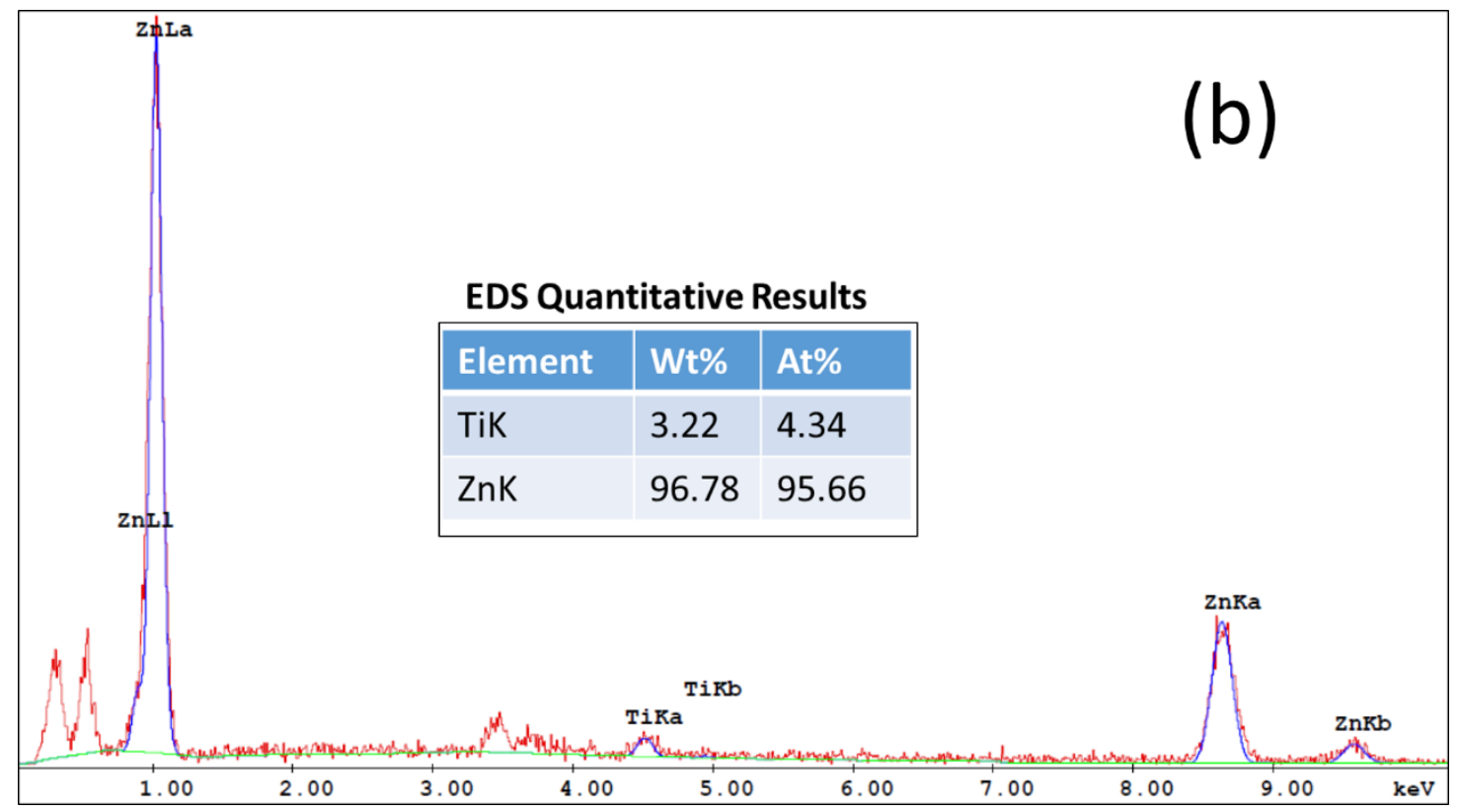

Figure 4. EDX spectrum of ZT films coated with $\mathrm{TiO}_{2}$ by (a) 100 layers of ALD and (b) $\mathrm{TiCl}_{4}$ treatment 


\section{Effect of number of ALD cycles.}
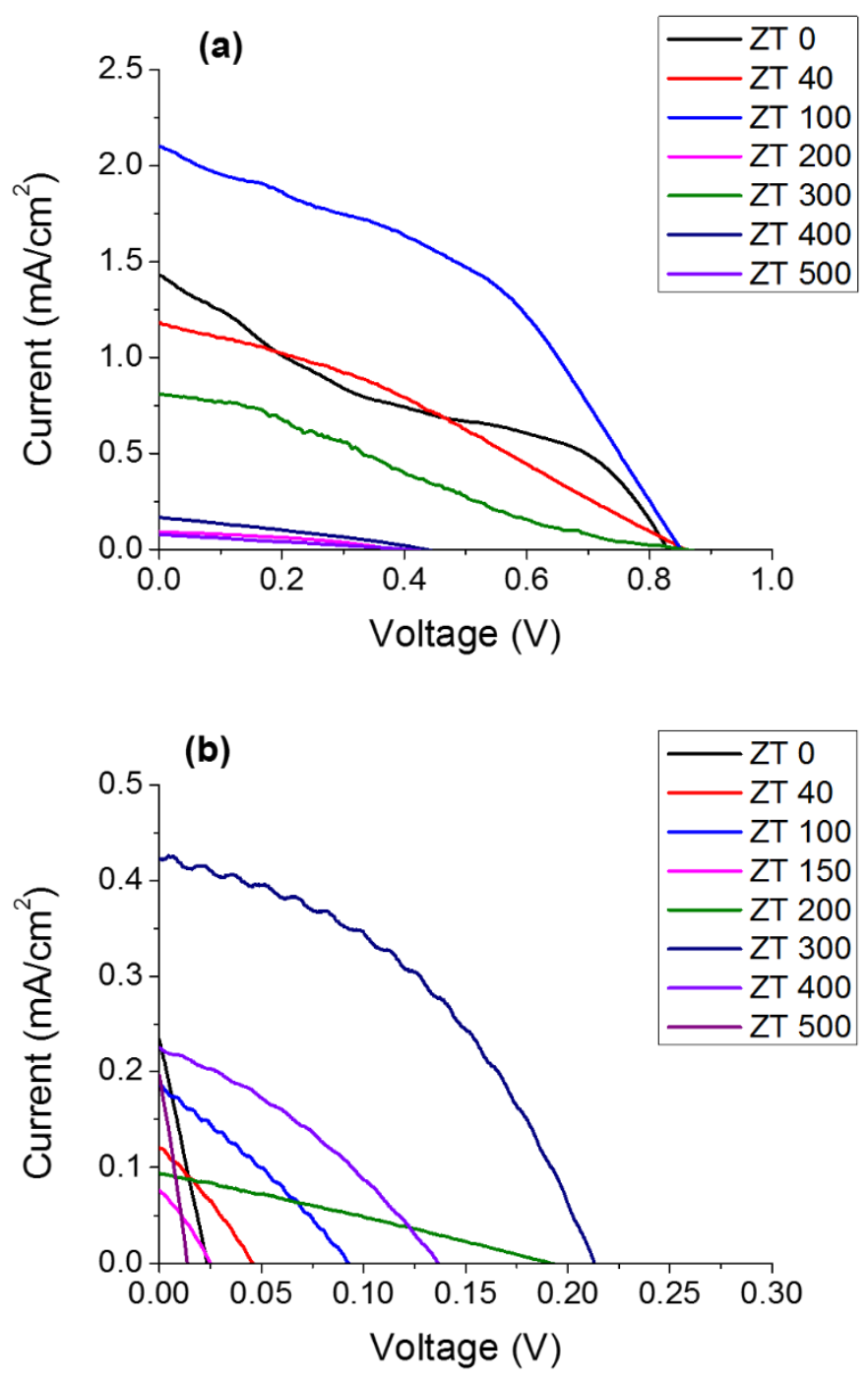

Figure 5. Current-voltage (J-V) characteristics for solar cells using ZT films with 0-500 ALD cycles and (a) $\mathrm{I}^{-} / \mathrm{I}_{3}^{-}$or (b) $\mathrm{Fc} / \mathrm{Fc}^{+}$electrolytes, under $100 \mathrm{~mW} / \mathrm{cm}^{2}$ AM $1.5 \mathrm{G}$ simulated sunlight

The performance of DSSC devices with different numbers of $\mathrm{TiO}_{2} \mathrm{ALD}$ layers over ZT electrodes is shown in Figure 5. In both $\mathrm{I}^{-} / \mathrm{I}^{-}$(Figure 5a) and $\mathrm{Fc} / \mathrm{Fc}^{+}$(Figure 5b) electrolytes, thin ALD coatings improved performance until an optimum thickness was reached, after which the current and voltage decreased significantly. Thin ALD layers of $\mathrm{TiO}_{2}$ do not crystallize even upon sintering [29]. The amorphous coating lacks abundant electronic states to effectively relay charges 
between the underlying $\mathrm{TiO}_{2}$ or $\mathrm{ZnO}$ and species outside the coating such as dyes and triiodide, forcing such exchange to occur by tunneling, reducing electron transfer rates. Dye injection efficiency is reduced only slightly, since the dye's electron injection rate is orders of magnitude faster than its excited state decay [9]. But the slower recombination kinetics tilt the competition between electron transport and recombination toward the former, resulting in better charge collection. In competition with this favorable effect, the filling in of pores results in a reduction of surface area and a reduced amount of adsorbed dye, as shown in Figure 6. The dye loading is greatly decreased as the ALD coating becomes thicker.

The optimal number of ALD cycles iodide/triiodide electrolyte is 100 (Figure 5a). In an electrolyte with ferrocene/ferrocenium, the optimum is $300 \mathrm{ALD}$ cycles (Figure $5 \mathrm{~b}$ ). $\mathrm{Fc} / \mathrm{Fc}^{+}$has much higher rates of recombination with electrons in $\mathrm{TiO}_{2}$ than iodide/triiodide. This results in thicker optimal blocking layer for $\mathrm{Fc} / \mathrm{Fc}^{+}$, since it is worth sacrificing additional dye loading in order to further reduce the high recombination rate.

\section{$\mathrm{TiCl}_{4}$ blocking layer}

In contrast to the sharp drop in dye loading with even the thinnest ALD coatings used in this study, the $\mathrm{TiCl}_{4}$ treatment results a slight increase in dye loading (Figure 6). The $\mathrm{TiCl}_{4}$-treated hybrid ZT film carries about $7 \%$ more dye than an untreated ZT film. A comparison of the current-voltage characteristic of untreated, optimally ALD-treated, and $\mathrm{TiCl}_{4}$-treated hybrid ZT films is shown in Figure 7 . The $\mathrm{TiCl}_{4}$ treatment leads to a remarkable increase in the short-circuit current density $\left(J_{\mathrm{SC}}\right)$ by a factor of three compared to untreated ZT film, and by a factor of 2.2 versus the best ALD-treated film. Clearly, the 7\% boost in dye loading does not account for the current increase. 
We note that the $\mathrm{TiCl}_{4}$ treatment also results in a reduced open-circuit voltage ( $\left.V_{\mathrm{OC}}\right)$ by about 90 $\mathrm{mV}$ versus the untreated film, and about $110 \mathrm{mV}$ versus the ALD-treated film. This is despite the fact that the $\mathrm{TiCl}_{4}$ treatment is known to reduce recombination by passivating surface defects in the $\mathrm{TiO}_{2}[30]$. Various defects can take place on the surface of the $\mathrm{TiO}_{2}$ nanoparticles due to the presence of the oxygen vacancies, bridge bonded oxygen, hydroxyl groups and fivefold coordinated Ti atoms [31, 32]. Photoluminescence measurements have shown these defects to be reduced by the $\mathrm{TiCl}_{4}$ treatment $[33,34]$. This effect is seen in the dark current data for the DSSC devices (Figure 8), which indicate that both coatings substantially reduce recombination compared to the uncoated film, although the ALD coating has a larger effect on recombination.

These findings can be easily reconciled thanks to the work of Sommeling et al. [28], who found that the $\mathrm{TiCl}_{4}$ treatment results in a positive shift of the $\mathrm{TiO}_{2}$ conduction band by about $100 \mathrm{mV}$. This has the effect of reducing the voltage, despite the reduced recombination, while increasing injection efficiency due to the larger driving force from the dye LUMO to the $\mathrm{TiO}_{2}$ conduction band. The result is a $\mathrm{TiCl}_{4}$-treated film giving a smaller $V_{\mathrm{OC}}$ but a much larger $J_{\mathrm{SC}}$ and an overall higher power conversion efficiency, specifically $1.685 \%$ for the $\mathrm{TiCl}_{4}$-treated film versus $0.71 \%$ for the 100 -cycle ALD-coated film and $0.365 \%$ for the uncoated film. Our thinnest ALD coating, using 40 cycles, results in a film thickness of about $1.6 \mathrm{~nm}$, which is comparable to the reported $\mathrm{TiCl}_{4}$ thickness of $1 \mathrm{~nm}$ [28], given that both measures are approximate. It can be seen in Figure 5(a) that the 40-cycle ALD coating results in DSSC performance not significantly better than an untreated film, and far worse than the $\mathrm{TiCl}_{4}$ coating of similar thickness. Therefore, the shift of the conduction band produced by the $\mathrm{TiCl}_{4}$ treatment and corresponding improvement in charge injection from the dyes has a far greater effect than the reduction of recombination current, which is also provided by the ALD coating but without a similar effect on current. 


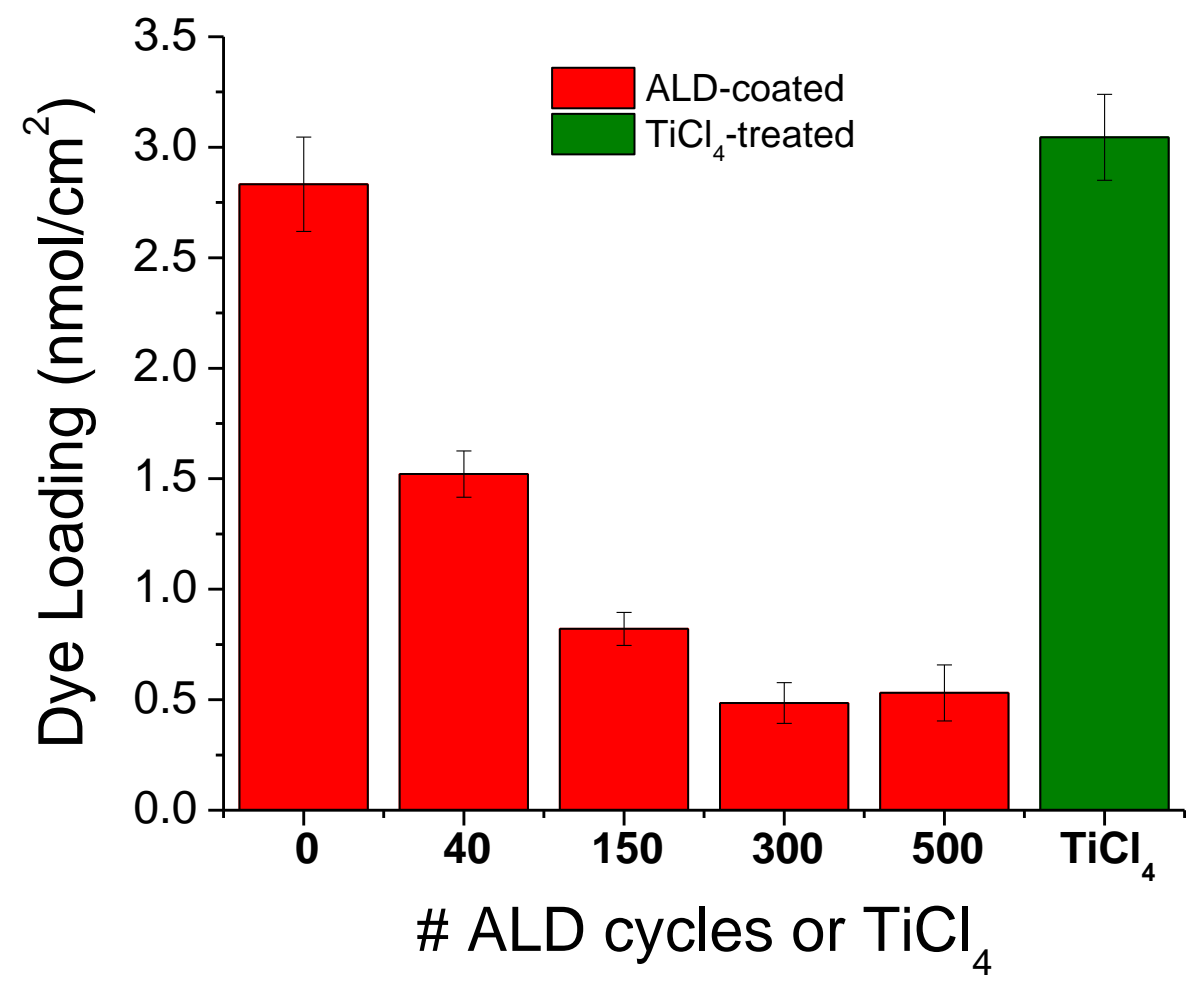

Figure 6. Uptake of $\mathrm{N} 719$ by a $\mathrm{ZnO}$ nanorod- $\mathrm{TiO}_{2}$ nanoparticle hybrid film coated with $\mathrm{TiO}_{2}$ by $0-500$ cycles of ALD or by $\mathrm{TiCl}_{4}$ treatment 


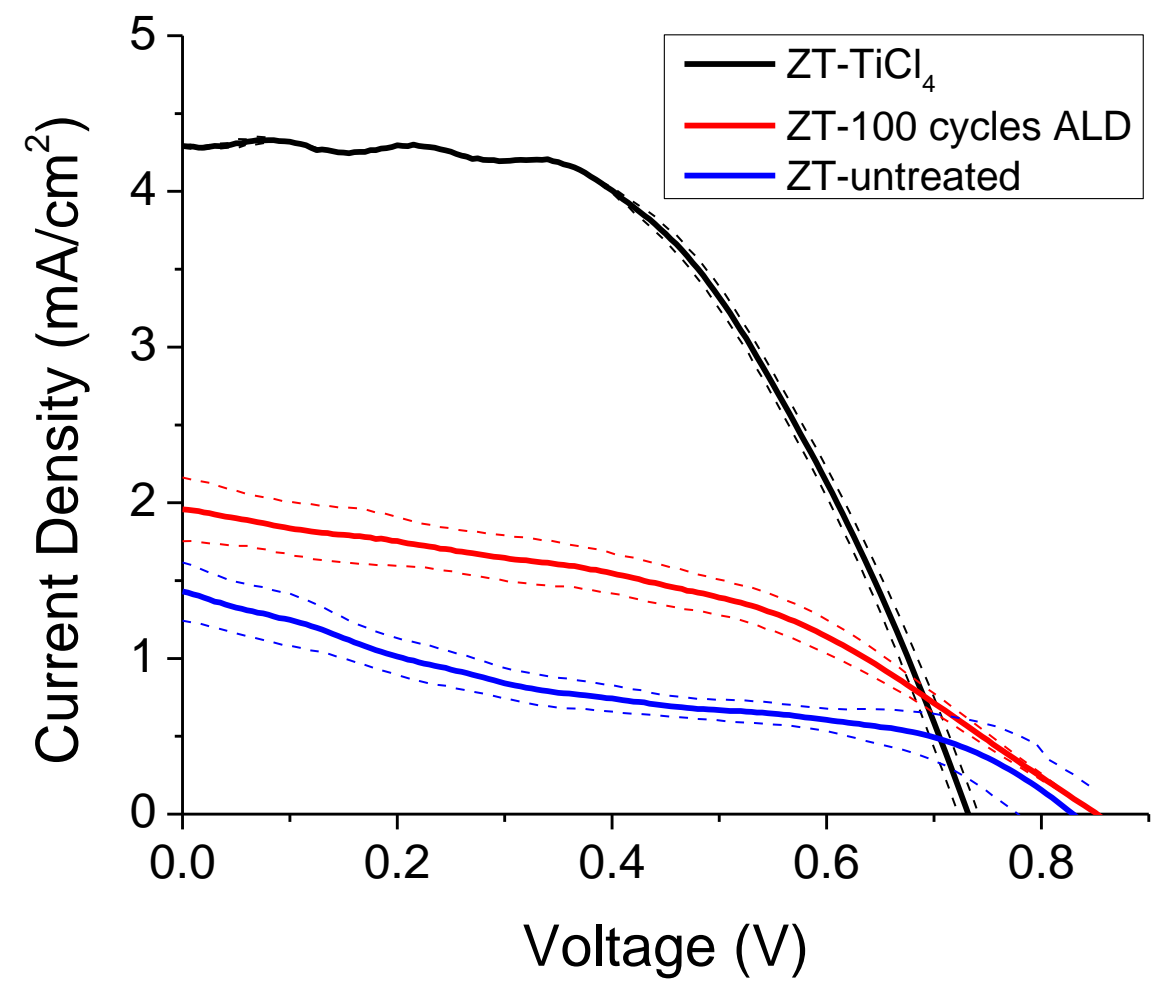

Figure 7. Current-voltage characteristics of DSSCs made from ZT hybrid films untreated or coated with $\mathrm{TiO}_{2}$ by 100 cycles of $\mathrm{ALD}$ or by $\mathrm{TiCl}_{4}$ treatment. Means of triplicate samples are shown, with dotted lines indicating 1 SD 


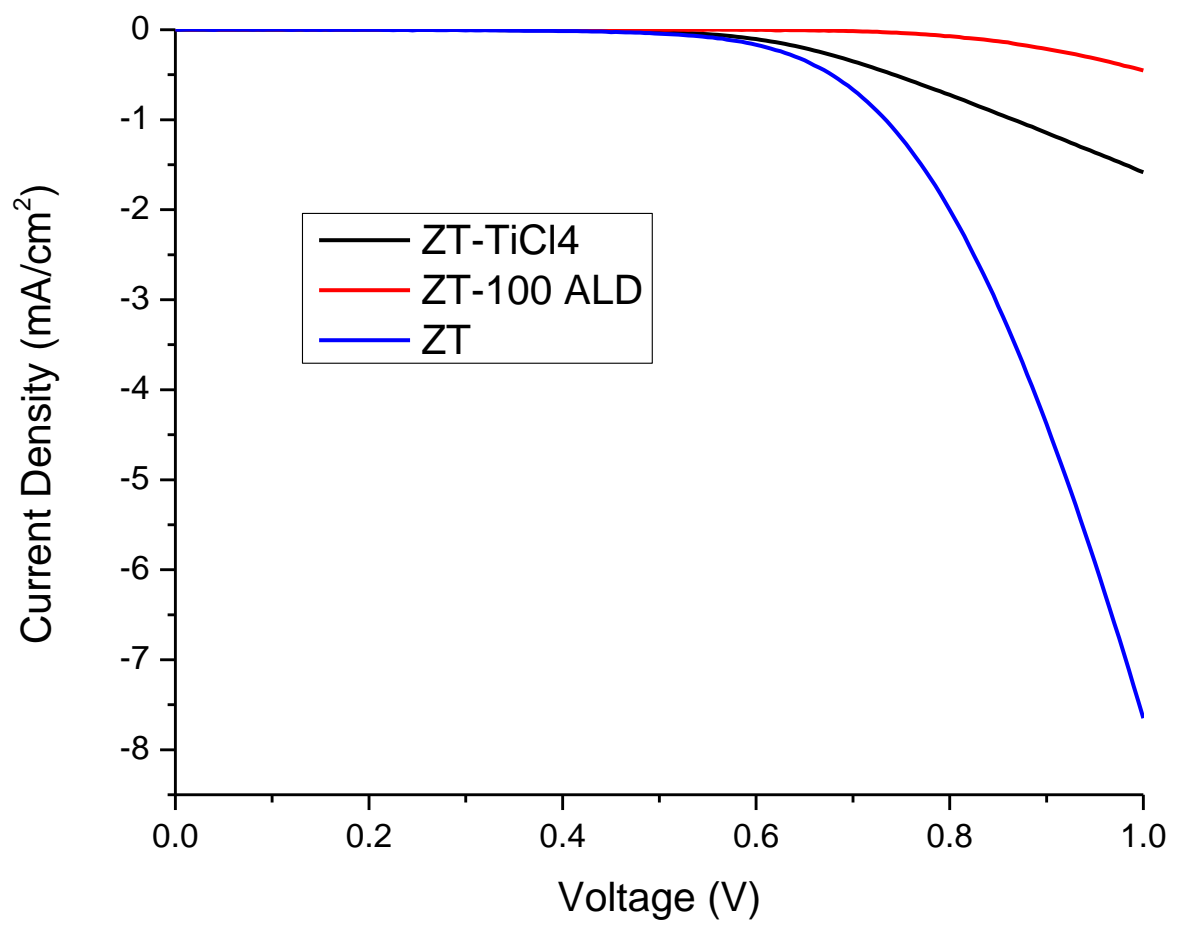

Figure 8. Dark current measurements of $\mathrm{TiCl}_{4}$ treated and ALD coated ZT films.

\section{Conclusions}

Nanocomposite films of $\mathrm{ZnO}$ nanorods coated with $\mathrm{TiO}_{2}$ nanoparticles were coated with $\mathrm{TiO}_{2}$ blocking layers by $\mathrm{ALD}$ or by $\mathrm{TiCl}_{4}$ treatment. At the optimal thickness of 100 cycles (about 4 $\mathrm{nm}$ ), the ALD coating significantly improves photovoltaic performance by slightly enhancing $V_{\mathrm{OC}}$ and significantly improving $J_{\mathrm{SC}}$. However, thicker ALD layers block pores in the $\mathrm{TiO}_{2}$ layer and greatly reduce surface area and dye loading, leading to low photocurrents. $\mathrm{TiCl}_{4}$-treated films have a reduced $V_{\mathrm{OC}}$ by about $0.1 \mathrm{~V}$ but make up for this with a greatly improved photocurrent, leading to significantly better DSSC performance than either untreated or ALD-coated $\mathrm{TiO}_{2}$, which is 
attributed to a downward shift of the $\mathrm{TiO}_{2}$ conduction band that reduces photovoltage but improves charge injection from the adsorbed dyes.

\section{Acknowledgements}

This material is based on work supported by the National Science Foundation under Grant No. CBET-1332022. XRD and SEM were carried out at the Center for Clean Energy Engineering at the University of Connecticut. The authors thank Prof. S.L. Suib for kindly allowing us to use the atomic layer deposition facility.

\section{References}

[1] P.J. Cameron, L.M. Peter, S. Hore, How Important is the Back Reaction of Electrons via the Substrate in Dye-Sensitized Nanocrystalline Solar Cells?, The Journal of Physical Chemistry B, 109 (2004) 930-936.

[2] T.W. Hamann, O.K. Farha, J.T. Hupp, Outer-sphere redox couples as shuttles in dye-sensitized solar cells. Performance enhancement based on photoelectrode modification via atomic layer deposition, J. Phys. Chem. C, 112 (2008) 19756-19764.

[3] S.M. Feldt, E.A. Gibson, E. Gabrielsson, L. Sun, G. Boschloo, A. Hagfeldt, Design of Organic Dyes and Cobalt Polypyridine Redox Mediators for High-Efficiency Dye-Sensitized Solar Cells, J. Am. Chem. Soc., 132 (2010) 16714-16724.

[4] I.R. Perera, A. Gupta, W. Xiang, T. Daeneke, U. Bach, R.A. Evans, C.A. Ohlin, L. Spiccia, Introducing manganese complexes as redox mediators for dye-sensitized solar cells, Physical Chemistry Chemical Physics, 16 (2014) 12021-12028.

[5] A. Yella, H.-W. Lee, H.N. Tsao, C. Yi, A.K. Chandiran, M.K. Nazeeruddin, E.W.-G. Diau, C.Y. Yeh, S.M. Zakeeruddin, M. Grätzel, Porphyrin-Sensitized Solar Cells with Cobalt (II/III)Based Redox Electrolyte Exceed 12 Percent Efficiency, Science, 334 (2011) 629-634.

[6] S. Ito, P. Liska, P. Comte, R. Charvet, P. Pechy, U. Bach, L. Schmidt-Mende, S.M. Zakeeruddin, A. Kay, M.K. Nazeeruddin, M. Gratzel, Control of dark current in photoelectrochemical $\left(\mathrm{TiO}_{2} / \mathrm{I}^{-} / \mathrm{I}_{3}{ }^{-}\right)$and dye-sensitized solar cells, Chemical Communications, (2005) 4351-4353.

[7] E. Guillén, E. Azaceta, A. Vega-Poot, J. Idígoras, J. Echeberría, J.A. Anta, R. Tena-Zaera, $\mathrm{ZnO} / \mathrm{ZnO}$ Core-Shell Nanowire Array Electrodes: Blocking of Recombination and Impressive Enhancement of Photovoltage in Dye-Sensitized Solar Cells, J. Phys. Chem. C, 117 (2013) 1336513373.

[8] S.-J. Roh, R.S. Mane, S.-K. Min, W.-J. Lee, C.D. Lokhande, S.-H. Han, Achievement of 4.51\% conversion efficiency using $\mathrm{ZnO}$ recombination barrier layer in $\mathrm{TiO}_{2}$ based dye-sensitized solar cells, Applied Physics Letters, 89 (2006) 253512-253515. 
[9] E. Palomares, J.N. Clifford, S.A. Haque, T. Lutz, J.R. Durrant, Control of Charge Recombination Dynamics in Dye Sensitized Solar Cells by the Use of Conformally Deposited Metal Oxide Blocking Layers, Journal of the American Chemical Society, 125 (2002) 475-482. [10] T.C. Li, M.r.S. Góes, F. Fabregat-Santiago, J. Bisquert, P.R. Bueno, C. Prasittichai, J.T. Hupp, T.J. Marks, Surface Passivation of Nanoporous $\mathrm{TiO}_{2}$ via Atomic Layer Deposition of $\mathrm{ZrO}_{2}$ for Solid-State Dye-Sensitized Solar Cell Applications, The Journal of Physical Chemistry C, 113 (2009) 18385-18390.

[11] K.E. Roelofs, T.P. Brennan, J.C. Dominguez, C.D. Bailie, G.Y. Margulis, E.T. Hoke, M.D. McGehee, S.F. Bent, Effect of A12O3 Recombination Barrier Layers Deposited by Atomic Layer Deposition in Solid-State CdS Quantum Dot-Sensitized Solar Cells, The Journal of Physical Chemistry C, 117 (2013) 5584-5592.

[12] A. Kay, M. Grätzel, Dye-Sensitized Core-Shell Nanocrystals: Improved Efficiency of Mesoporous Tin Oxide Electrodes Coated with a Thin Layer of an Insulating Oxide, Chemistry of Materials, 14 (2002) 2930-2935.

[13] P. Docampo, P. Tiwana, N. Sakai, H. Miura, L. Herz, T. Murakami, H.J. Snaith, Unraveling the Function of an $\mathrm{MgO}$ Interlayer in Both Electrolyte and Solid-State $\mathrm{SnO}_{2}$ Based Dye-Sensitized Solar Cells, The Journal of Physical Chemistry C, 116 (2012) 22840-22846.

[14] P. Ramasamy, M.-S. Kang, H.-J. Cha, J. Kim, Highly efficient dye-sensitized solar cells based on $\mathrm{HfO}_{2}$ modified $\mathrm{TiO}_{2}$ electrodes, Materials Research Bulletin, 48 (2013) 79-83.

[15] M.-H. Kim, Y.-U. Kwon, Semiconductor CdO as a Blocking Layer Material on DSSC Electrode: Mechanism and Application, The Journal of Physical Chemistry C, 113 (2009) 1717617182.

[16] D. Jiang, Y. Hao, R. Shen, S. Ghazarian, A. Ramos, F. Zhou, Effective Blockage of the Interfacial Recombination Process at $\mathrm{TiO}_{2}$ Nanowire Array Electrodes in Dye-Sensitized Solar Cells, ACS Applied Materials \& Interfaces, 5 (2013) 11906-11912.

[17] B. Peng, G. Jungmann, C. Jäger, D. Haarer, H.-W. Schmidt, M. Thelakkat, Systematic investigation of the role of compact $\mathrm{TiO}_{2}$ layer in solid state dye-sensitized $\mathrm{TiO}_{2}$ solar cells, Coordination Chemistry Reviews, 248 (2004) 1479-1489.

[18] S.M. Waita, B.O. Aduda, J.M. Mwabora, G.A. Niklasson, C.G. Granqvist, G. Boschloo, Electrochemical characterization of $\mathrm{TiO}_{2}$ blocking layers prepared by reactive DC magnetron sputtering, Journal of Electroanalytical Chemistry, 637 (2009) 79-83.

[19] J.G. Lee, J.H. Cheon, H.S. Yang, D.K. Lee, J.H. Kim, Enhancement of Photovoltaic Performance in Dye-Sensitized Solar Cells with the Spin-Coated $\mathrm{TiO}_{2}$ Blocking Layer, Journal of Nanoscience and Nanotechnology, 12 (2012) 6026-6030.

[20] H. Yu, S. Zhang, H. Zhao, G. Will, P. Liu, An efficient and low-cost $\mathrm{TiO}_{2}$ compact layer for performance improvement of dye-sensitized solar cells, Electrochimica Acta, 54 (2009) 13191324.

[21] M. Thelakkat, C. Schmitz, H.W. Schmidt, Fully Vapor-Deposited Thin-Layer Titanium Dioxide Solar Cells, Advanced Materials, 14 (2002) 577-581.

[22] J. Guo, C. She, T. Lian, Effect of Insulating Oxide Overlayers on Electron Injection Dynamics in Dye-Sensitized Nanocrystalline Thin Films $\dagger$, The Journal of Physical Chemistry C, 111 (2007) 8979-8987.

[23] A.K. Chandiran, A. Yella, M. Stefik, L.-P. Heiniger, P. Comte, M.K. Nazeeruddin, M. Grätzel, Low-Temperature Crystalline Titanium Dioxide by Atomic Layer Deposition for DyeSensitized Solar Cells, ACS Appl. Mater. Interf., 5 (2013) 3487-3493. 
[24] T.P. Brennan, J.R. Bakke, I.K. Ding, B.E. Hardin, W.H. Nguyen, R. Mondal, C.D. Bailie, G.Y. Margulis, E.T. Hoke, A. Sellinger, M.D. McGehee, S.F. Bent, The importance of dye chemistry and $\mathrm{TiCl} 4$ surface treatment in the behavior of $\mathrm{Al}_{2} \mathrm{O}_{3}$ recombination barrier layers deposited by atomic layer deposition in solid-state dye-sensitized solar cells, Physical Chemistry Chemical Physics, 14 (2012) 12130-12140.

[25] V. Manthina, J.P. Correa Baena, G. Liu, A.G. Agrios, $\mathrm{ZnO}-\mathrm{TiO}_{2}$ Nanocomposite Films for High Light Harvesting Efficiency and Fast Electron Transport in Dye-Sensitized Solar Cells, The Journal of Physical Chemistry C, 116 (2012) 23864-23870.

[26] N. Sakai, T. Miyasaka, T.N. Murakami, Efficiency Enhancement of ZnO-Based DyeSensitized Solar Cells by Low-Temperature $\mathrm{TiCl}_{4}$ Treatment and Dye Optimization, J. Phys. Chem. C, 117 (2013) 10949-10956.

[27] J.P. Correa Baena, A.G. Agrios, Antimony-Doped Tin Oxide Aerogels as Porous Electron Collectors for Dye-Sensitized Solar Cells, J. Phys. Chem. C, 118 (2014) 17028-17035.

[28] P.M. Sommeling, B.C. O'Regan, R.R. Haswell, H.J.P. Smit, N.J. Bakker, J.J.T. Smits, J.M. Kroon, J.A.M. van Roosmalen, Influence of a $\mathrm{TiCl}_{4}$ post-treatment on nanocrystalline $\mathrm{TiO}_{2}$ films in dye-sensitized solar cells, J. Phys. Chem. B, 110 (2006) 19191-19197.

[29] M. Law, L.E. Greene, A. Radenovic, T. Kuykendall, J. Liphardt, P. Yang, $\mathrm{ZnO}-\mathrm{Al}_{2} \mathrm{O}_{3}$ and $\mathrm{ZnO}-\mathrm{TiO}_{2}$ core-shell nanowire dye-sensitized solar cells, J. Phys. Chem. B, 110 (2006) 2265222663.

[30] J. Kim, H. Choi, C. Nahm, C. Kim, S. Nam, S. Kang, D.-R. Jung, J.I. Kim, J. Kang, B. Park, The role of a $\mathrm{TiCl}_{4}$ treatment on the performance of CdS quantum-dot-sensitized solar cells, Journal of Power Sources, 220 (2012) 108-113.

[31] S. Wendt, P.T. Sprunger, E. Lira, G.K.H. Madsen, Z. Li, J.Ø. Hansen, J. Matthiesen, A. Blekinge-Rasmussen, E. Lægsgaard, B. Hammer, F. Besenbacher, The Role of Interstitial Sites in the Ti3d Defect State in the Band Gap of Titania, Science, 320 (2008) 1755-1759.

[32] S.M. Prokes, J.L. Gole, X. Chen, C. Burda, W.E. Carlos, Defect-Related Optical Behavior in Surface Modified $\mathrm{TiO}_{2}$ Nanostructures, Advanced Functional Materials, 15 (2005) 161-167.

[33] F.J. Knorr, D. Zhang, J.L. McHale, Influence of TiCl4 Treatment on Surface Defect Photoluminescence in Pure and Mixed-Phase Nanocrystalline TiO2, Langmuir, 23 (2007) 86868690.

[34] H.O. Seo, S.-Y. Park, W.H. Shim, K.-D. Kim, K.H. Lee, M.Y. Jo, J.H. Kim, E. Lee, D.-W. Kim, Y.D. Kim, D.C. Lim, Ultrathin TiO2 Films on ZnO Electron-Collecting Layers of Inverted Organic Solar Cell, The Journal of Physical Chemistry C, 115 (2011) 21517-21520. 